\title{
Implementation of Pedagogical Content Knowledge (PCK) of Mathematics Teachers in Teaching Practice: A Case Study
}

\author{
Maryono $^{1,2}$, Akbar Sutawidjaja $^{2}$, Subanji $^{2} \&$ Santi Irawati ${ }^{2}$ \\ ${ }^{1}$ Department of Mathematics Education, Institut Agama Islam Negeri (IAIN) Tulungagung, Indonesia \\ ${ }^{2}$ Department of Mathematics, Universitas Negeri Malang, Indonesia \\ Correspondence: Maryono, Department of Mathematics Education, Institut Agama Islam Negeri (IAIN) \\ Tulungagung, Jalan Mayor Sujadi Timur 46 Tulungagung, Indonesia. Tel: 62-355-321-513. E-mail: \\ mario_stain@yahoo.com
}

Received: September 5, 2016

Accepted: October 12, $2016 \quad$ Online Published: February 27, 2017

doi:10.5539/ies.v10n3p11

URL: https://doi.org/10.5539/ies.v10n3p11

\begin{abstract}
This study aims to describe the implementation of pedagogical content knowledge (PCK) of mathematics teachers in the teaching practice of the material system of linear equations of two variables (SLETV). The approach used is a qualitative case study. The main instrument is the researchers themselves and the supporting instruments is a vignette sheet, sheet Content Representation (CoRe), and video tape recorders (Handycam). Research procedure includes providing vignette sheets and sheets of CoRe, making instructional videos and conducting the interview. Data were analyzed using frameworks Karahasan. The results showed that the subject 1 (S1) found that the implementation of the PCK S1 when teaching increased from PCK S1 prior to the implementation of the teaching practice, while the subject 2 (S2) found that the implementation of the PCK S2 upon teaching declined from PCK S2 prior to the implementation of the teaching practice.
\end{abstract}

Keywords: the implementation of pedagogical content knowledge (PCK), teaching practice, system of linear equations of two variables (SLETV)

\section{Introduction}

\subsection{Introduce the Problem}

Research on the pedagogical content knowledge (PCK) and the teachers' teaching practice has been done by many previous investigators. But they rarely research has focused on the implementation of PCK in teaching practice. Therefore it is necessary to research specifically explores how teachers implement its PCK in teaching practice. System of Linear Equation of Two Variable (SLETV) was selected as the material in the study because these materials often lead to misconceptions students have difficulties, especially in solving problems that have infinitely many solutions or who do not have a solution.

\subsection{Pedagogical Content Knowledge (PCK)}

Pedagogical Content Knowledge (PCK) introduced by Shulman (1986) is an issue that continues to grow today. PCK is described as a result of the integration between the understanding of teaching materials (content knowledge) and understanding the way of educating (pedagogical knowledge) that blend into one that needs to be owned by a teacher. Shuell and Shulman (in Eggen \& Kauchak, 2007) theorized that PCK is an understanding of effective learning methods to explain the specific material, as well as an understanding of what makes a particular material is easy or difficult to learn.

Some researchers have explained about the components of PCK (Shulman, 1986; Grossman's, 1990; Rollnick et.al., 2008). Shulman (1986) mentions three components of PCK: (1) knowledge of topics regularly taught in one's subject area, (2) knowledge of forms of representation of those ideas, and (3) knowledge of students' understanding of the topics. Grossman's (1990) state that the construct of PCK includes four central components: (1) conception of teaching purposes-knowledge and beliefs about the purposes for teaching a subject at different grade levels; (2) knowledge of students, including students' understanding, conceptions, and misconceptions of particular topics in a subject matter; (3) curricular knowledge, which includes knowledge of curriculum materials available for teaching particular subject matter and knowledge about both the horizontal and vertical curricula for a subject; as well as (4) knowledge of instructional strategies and representations for teaching particular 
topics. While Rollnick et al. (2008) found PCK is a mixture of the four areas of the knowledge base for teaching, namely: a) Content Knowledge; b) Knowledge of learners; c) General Pedagogical Knowledge; and d) Knowledge of Context. In this study, researchers used the Rollnick et al.'s (2008) opinion and focus on the three components of the first with the little change in terms is for general pedagogical knowledge into knowledge of teaching. Rollnick Opinion been selected because the components mentioned are the core components of PCK and can accommodate the components mentioned by another expert.

\subsection{Teaching Practice}

In early studies of teachers' practices, practice was mostly regarded as "actions", "acts" or "behaviours". But this evolved in interesting ways over the years as suggested by the following examples. Simon and Tzur (1997) discussed practice as including what the teacher does, knows, believes and intends, adding: "we see the teacher's practice as a conglomerate that cannot be understood looking at parts from the whole (i.e., looking only at beliefs, or questioning, or mathematical knowledge, etc.)". Skott (1999) underlined the importance of motives in the study of teachers' practices. Saxe (1999) considered practices as "recurrent socially organized activities that permeate daily life". A key assumption is that there is a reflective relation between individual activities and practices, since the activities of the individual are constitutive of practices and, at the same time, practices give form and social meaning to the activities of the individual. Boaler (2003) described practices as "the recurrent activities and norms that develop in classrooms over time, in which teachers and students engage". Common to Boaler and Saxe is the notion of stability and recurrence of practices. However, Saxe emphasized their socially organized nature and Boaler considered not only activities but also norms.

If we regard the study of the practices of social actors in their natural contexts to be: the activities, the recurrence, the social setting and the knowledge, meanings and motives of the participants, then teachers' practices can be viewed as the activities that they regularly conduct, taking into consideration their working context, and their meanings and intentions. This includes the social structure of the context and its many layers - classroom, school, community, professional structure and educational and social system. But this can be problematic, as noted by Even and Schwartz (2002) who discussed the issue of competing interpretations of teachers' practice and its implications for research. They showed that any given theoretical framework tends to ask its own kind of questions and leads naturally to a different picture of the situation. They suggested that practice is too complex to be understood by only one perspective but pointed out that while combining several theoretical approaches may seem an appealing proposal, it may raise questions of legitimacy that must be addressed by researchers. However, they leave it as an open question to be addressed by researchers.

\subsection{Framework for Analyzing Implementation of PCK in Teaching Practice}

In this study, PCK of mathematics teachers and implementation on teaching practice will be analyzed using an analytical framework PCK of Karahasan (2010). This framework is chosen because it is a refinement of the previous framework, namely Thompson (1991) and Ebert (1993). The description of each component and the level presented in Table 1 as follows.

Table 1. The descriptions of PCK (Karahasan, 2010)

\begin{tabular}{|c|c|c|c|}
\hline $\begin{array}{l}\text { Component } \\
\text { of PCK }\end{array}$ & Level 0 & Level 1 & Level 2 \\
\hline $\begin{array}{l}\text { Knowledge of } \\
\text { Teaching }\end{array}$ & 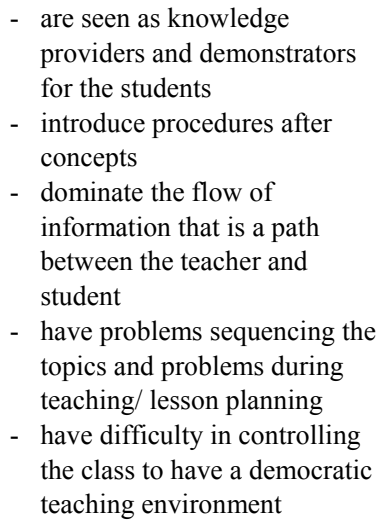 & $\begin{array}{l}\text { - not only provide necessary rules } \\
\text { and procedures but also help } \\
\text { students to develop meaning and } \\
\text { understanding } \\
\text { - view their role as one of advising, } \\
\text { appraising, and admonishing } \\
\text { - still dominate the flow of } \\
\text { information which is a path } \\
\text { between teacher to the student } \\
\text { - only have problems sequencing } \\
\text { the problems during teaching/ } \\
\text { lesson planning } \\
\text { - sometimes controls the class to } \\
\text { have a democratic teaching } \\
\text { environment }\end{array}$ & 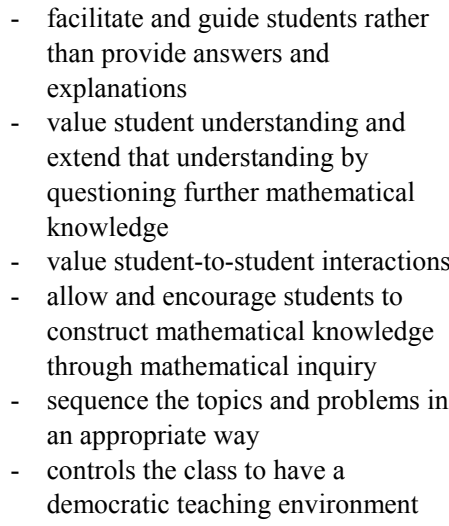 \\
\hline $\begin{array}{l}\text { Knowledge of } \\
\text { Learners }\end{array}$ & $\begin{array}{l}\text { - have difficulty in diagnosing } \\
\text { errors of the students }\end{array}$ & $\begin{array}{l}\text { - diagnosing some of the student } \\
\text { errors and even if they address the }\end{array}$ & $\begin{array}{l}\text { - easily diagnose student errors and } \\
\text { address students difficulties }\end{array}$ \\
\hline
\end{tabular}




\begin{tabular}{|c|c|c|c|}
\hline & $\begin{array}{l}\text { - view responding to students } \\
\text { misconceptions as an } \\
\text { opportunity for them to tell the } \\
\text { student the direct rule or } \\
\text { procedure } \\
\text { - } \text { have difficulty in realizing } \\
\text { students needs for } \\
\text { understanding }\end{array}$ & $\begin{array}{l}\text { error they focus on the surface } \\
\text { futures of the error } \\
\text { - solve similar numerical examples, } \\
\text { practice problems but also } \\
\text { appreciate the importance of } \\
\text { discussion } \\
\text { - from time to time realize students' } \\
\text { needs for understanding and } \\
\text { prepare learning environments. }\end{array}$ & $\begin{array}{l}\text { - guide and facilitate students rather } \\
\text { than providing answers and } \\
\text { explanations } \\
\text { - aware of students" needs for } \\
\text { understanding and accordingly able } \\
\text { to create rich learning environments. }\end{array}$ \\
\hline $\begin{array}{l}\text { Content } \\
\text { Knowledge }\end{array}$ & 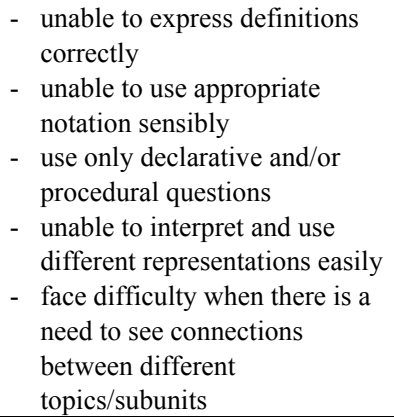 & $\begin{array}{l}\text { - express definitions correctly } \\
\text { - use appropriate notation sensibly } \\
\text { - still use declarative and/or } \\
\text { procedural questions } \\
\text { - interpret and use graphical and } \\
\text { other representations } \\
\text { - see connections between different } \\
\text { topics/subunits }\end{array}$ & $\begin{array}{l}\text { - } \quad \text { express definitions correctly } \\
\text { - } \quad \text { use appropriate notation sensibly } \\
\text { procedural, and conditional) in an } \\
\text { appropriate positions } \\
\text { - } \quad \text { interpret and use graphical and other } \\
\text { representations sensibly } \\
\text { - } \quad \text { see connections between different } \\
\text { topic/subunits and move among them } \\
\text { smoothly }\end{array}$ \\
\hline
\end{tabular}

\subsection{The Aim of the Study}

The purpose of the study was to describe the implementation of pedagogical content knowledge (PCK) of mathematics teachers in the teaching practice of the material system of linear equations of two variables. This research is expected to produce findings that are useful for the development of teachers knowledge in teaching especially pedagogical content knowledge.

\section{Method}

This study used a qualitative approach with case study. The case study is the description and intensive analysis of the phenomenon, a social unit, or systems that are limited by time and place (Bloomberg \& Volpe, 2008). Design of case studies conducted to gain in-depth understanding of the situation and meaning. Attention is preferred on process rather than results.

\subsection{Partisipant (Subject) Characteristics}

The study involved six mathematics teachers who teach high school in 10th grade. Six mathematics teachers were asked to fill PCK writing instruments and video taken during the implementation of learning materials Systems of Linear Equations 2 variables. Of the six teachers have 2 subjects with the criteria of teachers who experienced a shift from the PCK to PCK implementation in learning. The shift in question is a mismatch between teachers PCK with the implementation of PCK in teaching.

\subsection{Instruments}

There are two main type of instruments will be used, main and auxiliary instruments. The main instruments is the researchers themselves who act as planners, data collectors, data analysis, interpreters, and reporters of research results. The auxiliary instruments used in this study are vignette, content representation $(\mathrm{CoRe})$ and video recorder (handycam).

\subsection{Research Procedures}

The procedures in this study include the provision of writing instruments in the form of vignette sheets and CoRe sheet, making instructional videos, and conducting the interview. Interviews were conducted to obtain the classification of the object if there are things that are less obvious than the subject's response to the writing instrument and the teaching practice of the subject.

\subsection{Data Analysis}

Qualitative data analysis is the effort made by working with the data, organize data, sorted them into units that can be managed, synthesize, search and find patterns, find what is important and what is learned, and decide what can be narrated to others, activities in qualitative data analysis performed interactively and runs continuously until complete, so that the data is already saturated. Activities in the data analysis, namely data reduction, data presentation, and verification/conclusion. 


\section{Results and Discussion}

Here are presented results of research on the implementation of pedagogical content knowledge (PCK) of teachers in the teaching practice in the material system of linear equations of two variables along with the discussion of the findings of this research.

\subsection{Subject 1 (S1)}

\subsubsection{PCK of Subject 1 (S1)}

In the component of knowledge of teaching, subject S1 has been trying to build meaning and understanding to students, for example, to understand the meaning $0=1$, and $0=0$ on the outcome of the elimination or substitution of the students are asked to draw a graph of the SLETV, so that will be visible position of the two lines. It is as shown in the S1 response to the case 2 of vignette as follows:

\begin{tabular}{|c|c|}
\hline 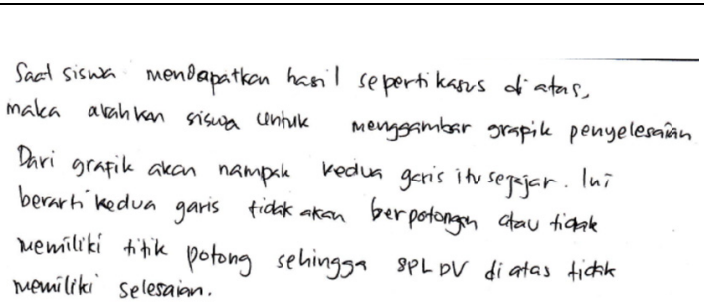 & $\begin{array}{l}\text { Translate in English: } \\
\text { when students get results like the above, then the } \\
\text { student is directed to draw graphics solution. of the } \\
\text { graph will look two lines parallel. This means that } \\
\text { both lines will not intersect or do not have a cut-off } \\
\text { point, so SLETV above concluded that have no } \\
\text { solution. }\end{array}$ \\
\hline
\end{tabular}

Figure 1. Response of S1 in vignette case 2

Based on the response seen that the $\mathrm{S} 1$ has been able to explain to the students how to interpret these cases, using the help of graphs. But when asked to provide an alternative explanation other than the graph S1 states do not know, as well as excerpts of the interview follows:

\begin{tabular}{|lll|}
\hline$R$ & $:$ & If I may know, what is the representation of a solution of SLETV? \\
$S 1$ & $:$ & In the form of cutting point Sir. So if the pictures, graphs of SPL in case 2 will be two parallel lines, so there is no point \\
& of intersection. Which means that the SPL does not have a solution. \\
$R$ & $: \quad$ Perhaps there are other explanations besides using graphs? \\
$S 1$ & $:$ No Sir.
\end{tabular}

But in naming the conceptual knowledge needed in studying this material S1 could not say with detailed and precise. While related to his role as assessor and reminders, $\mathrm{S} 1$ has been able to assess the results of the students' work, although still common errors in judgment. This is shown in response to S1 in the case 1 of vignette as follows.

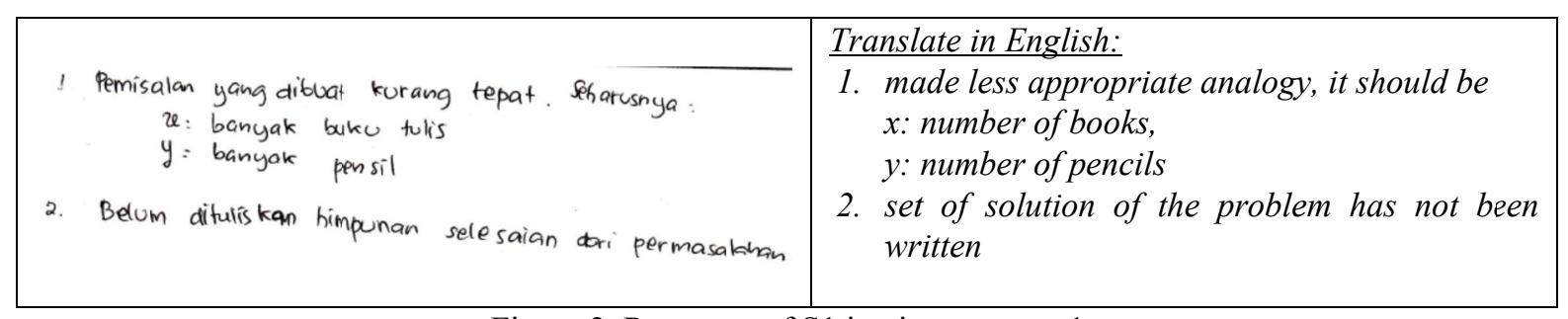

Figure 2. Response of S1 in vignette case 1

From these responses can be seen that the $\mathrm{S} 1$ can be stated that the analogy of the student is still not quite right, but $\mathrm{S} 1$ can not provide a more appropriate analogy.

It also is using assessment tests through formative tests or quizzes or non-test through observation of student performance. While the mentioned steps of learning S1 not mentioned in detail and sequence of how learning steps should be. This is as evident from the response S1 CoRe 6a as follows: 


\begin{tabular}{|c|c|c|c|c|}
\hline No. & \begin{tabular}{c|} 
Content \\
Representation \\
$($ CoRe $)$
\end{tabular} & $\begin{array}{c}\text { Konsep Pokok-1 } \\
\text { Persamaan Linear } 2 \text { Variabel }\end{array}$ & $\begin{array}{c}\text { Konssp Pokok-2 } \\
\text { Sistem Persamaan Linear } 2 \text { Variabel }\end{array}$ & $\begin{array}{l}\text { Konsep Pokok-3 } \\
\text { Penyelesaian Sistem Persamaan } \\
\text { Linear } 2 \text { Variabel }\end{array}$ \\
\hline 6. & $\begin{array}{l}\text { a.Bagaimana } \\
\text { langkah-langkah } \\
\text { (prosedur) } \\
\text { pembelajaran } \\
\text { yang Saudara } \\
\text { buat supaya siswa } \\
\text { bisa memahami } \\
\text { dengan baik } \\
\text { konsep ini. }\end{array}$ & $\begin{array}{l}\text { Cun menuiskon de papantidis } \\
\text { ' persamaan. linear oun } \\
\text { Variabel } \\
\text { Siswa diminta momberikan } \\
\text { conth I the - hal yang } \\
\text { terkait don PLDV }\end{array}$ & $\begin{array}{l}\text { Guru menuliskan di papantulis } \\
\text { 'Sistem persamaan linear } \\
\text { Du Variabel'. } \\
\text { fiswa siminta memberikan } \\
\text { contoh certa menyebutkan } \\
\text { hal - hac terkait SplDV }\end{array}$ & 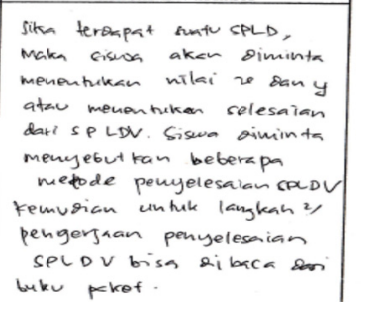 \\
\hline \multicolumn{5}{|c|}{ Translate in English: } \\
\hline No. & $\begin{array}{c}\text { Content } \\
\text { Representation } \\
(\mathrm{CoRe})\end{array}$ & $\begin{array}{l}\text { Central Concept-1 } \\
\text { LETV }\end{array}$ & $\begin{array}{l}\text { Central Concept-2 } \\
\text { SLETV }\end{array}$ & $\begin{array}{l}\text { Central Concept-3 } \\
\text { Solution of SLETV }\end{array}$ \\
\hline 6. & $\begin{array}{l}\text { a. Teaching } \\
\text { procedures } \\
\text { (and particular } \\
\text { reasons } \\
\text { for using these } \\
\text { to engage } \\
\text { with this idea). }\end{array}$ & $\begin{array}{l}\text { The teacher explains at } \\
\text { the blackboard linear } \\
\text { equations of two } \\
\text { variables } \\
\text { Students are asked to } \\
\text { provide examples of } \\
\text { things that are } \\
\text { associated with two } \\
\text { variable linear equations }\end{array}$ & $\begin{array}{l}\text { The teacher explains at the } \\
\text { blackboard system of } \\
\text { linear equations in two } \\
\text { variables } \\
\text { Students are asked to give } \\
\text { examples and mention } \\
\text { things related to systems of } \\
\text { linear equations of two } \\
\text { variables }\end{array}$ & $\begin{array}{l}\text { If there is a SLETV then the } \\
\text { student is required to determine } \\
\text { the value of } x \text { and y or } \\
\text { determine the solution of } \\
\text { SLETV. Students are asked to } \\
\text { name some solution methods } \\
\text { SLETV then to step work } \\
\text { SLETV solution can be read } \\
\text { from textbooks }\end{array}$ \\
\hline
\end{tabular}

Figure 3. Response of S1 in CoRe 6b

In response, it appears that $\mathrm{S} 1$ has not written learning steps detailed in each of the key concepts of SLETV. On the other side S1 is already able to write an experience for teaching SLETV how should the graphical method presented, ie, before the student can draw a graph LETV, then draw a graph SLETV not given beforehand. Based on the description it can be said that the knowledge of teaching of S1 is at "level 2".

On the other side, $\mathrm{S} 1$ has done a diagnosis of students' mistakes, as seen from the response of S1 in a case 5of vignette as follows.

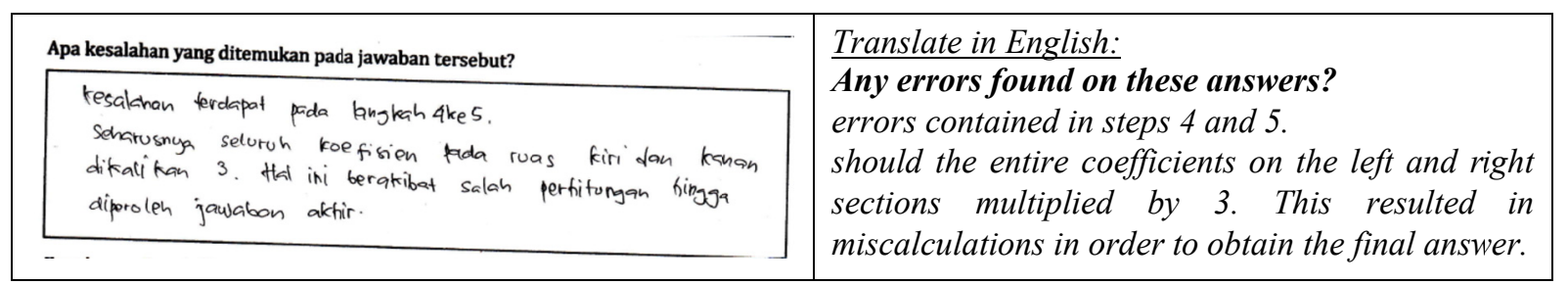

Figure 4. Response of S1 in vignette case 5 (part 1)

$\mathrm{S} 1$ is able to show the location of the mistakes made by the students, namely when multiplying the equation by 3 , not all tribes multiplied by three. However, there is something quite interesting when S1 prompted to correct students' mistakes, S1 writing through responses/comments as follows:

\begin{tabular}{|c|c|}
\hline Bagaimana Bapak/lbu memperbaikikesalahan yang dilakukan siswa tersebut? & Translate in English: \\
\hline $\begin{array}{c}4 x \frac{y}{3}+y=70 \quad 2 \times 3 \\
4 y+3 y=70 \\
7 y=70 \\
y=\frac{70}{7}=10\end{array}$ & $\begin{array}{l}\text { How do you fix the mistakes made by the student? } \\
\left.\begin{array}{l}4 \times y / 3+y=70 \\
4 y+3 y=70 \\
7 y=70\end{array}\right] \times 3\end{array}$ \\
\hline & $y=70 / 7=10$ \\
\hline
\end{tabular}

Figure 5. Response of S1 in vignette case 5 (part 2)

From these responses can be seen turns S1 at the time showed no improvement on the students' answers on the vignette just made a mistake on the right, which has not been multiplied by three. Additionally, S1 can determine the position of the mistakes made by students during the linear equation multiply by 3 , but when asked to write 
the correct answers count S1 is also to blame. While in facilitating students to solve problems, S1 demonstrated well, for example, to guide students in solving SLETV, if it produces $0=1$ or $0=0$ at the time eliminated or substituted then it is suggested to use graph. As in formulating learning goals, S1 has been able to formulate objectives SLETV quite well, whereas in explaining the importance of the materials submitted most still need to be improved. Furthermore, S1 associated with learning resources have not been able to mention learning resources other than books and worksheets, for example, the classroom environment, the internet, home environment, libraries, and others. Therefore, in general, it can be concluded that the knowledge of learners of S1 is at "level 1 ".

Additionally, S1 in stating the general form PLDV not disclose the terms in full, namely: the coefficient $x$ and $y$ are not both zero so that in response to the case of the form $0 x+0 y=0$ has not been able to explain it well. S1 also less appropriate analogy about the story into a variable, so that when students write analogy $x=$ notebooks and $y=$ pencils $\mathrm{S} 1$ considers the analogy is appropriate, as shown in response to $\mathrm{S} 1$ in the case vignette 1 above. As for the mention of procedural knowledge required in S1 SLETV material well enough to be able to mention (as shown in Figure 6 on the response of the S1 CoRe 5 b below).

\begin{tabular}{|c|c|c|c|c|c|}
\hline \begin{tabular}{|l|} 
b.Pengetahuan \\
prosedural apa \\
saja yang \\
mempunyai \\
kontribusi dalam \\
pembelajaran \\
konsep ini?
\end{tabular} & $\begin{array}{l}\text { - operasio } \\
\text { - Cauzkah } \\
\text { grafik }\end{array}$ & $\begin{array}{l}\text { Ijabar } \\
\text { menggamibar } \\
\text { PLOV }\end{array}$ & \multicolumn{2}{|c|}{$\begin{array}{l}\text { - operasi al jabar, } \\
\text { - langkah menggambar } \\
\text { grafik Spl-DV }\end{array}$} & arjabar \\
\hline \multicolumn{6}{|c|}{ Translate in English: } \\
\hline \multicolumn{2}{|c|}{$\begin{array}{l}\text { b. Procedural knowledge of } \\
\text { anything that has a } \\
\text { contribution in learning this } \\
\text { concept? }\end{array}$} & \multicolumn{2}{|c|}{$\begin{array}{l}\text { - algebra operations } \\
\text { - step drawing graphs } \\
\text { LETV }\end{array}$} & $\begin{array}{l}\text { - } \text { algebra operations } \\
\text { - step drawing graphs } \\
\text { SLETV }\end{array}$ & algebra operations \\
\hline
\end{tabular}

Figure 6. Response of S1 in CoRe 5b

Likewise, the subject is good enough to use graph representation as a response of cases 2, which provides an explanation for the case $0=1$ approach graph. On the other hand, S1 cannot mention the exact material necessary prerequisite to the concept of principal LETV, SLETV, and completion SLETV. So in general content knowledge of S1 is still at the "level 1" as well.

\subsubsection{Implementation of PCK of Subject 1}

In general, the practice of teaching knowledge S1 is good enough. It can be seen from of learning steps coherently are implemented and compliance with the lesson plan made the learning and use of the proper allocation of sufficient time. S1 also has been trying to create learning that enable students. This can be seen when explaining the material SLETV, S1 only explained globally, the rest students are asked to discuss with the group of their friends. But if there is material that the students feel elusive, the S1 also provides a more detailed explanation, for example, when describing the graphical method looks S1 explained in sufficient detail so that it looks students really understand. It is as shown in the screenshot below instructional video.

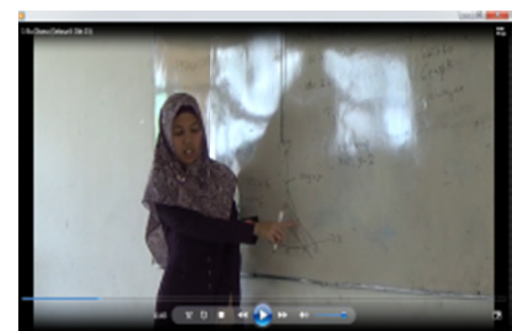

Figure 7. Instructional video screenshot of S1 part 1

At the time of material explanation, S1 also keep trying to engage students, such students are invited discussion to identify examples and are not examples of LETV, terms SLETV, and the possibility of settlement SLETV. In 
questioning and discussion techniques, S1 tried to give the widest opportunity for students to present any given task and provide the opportunity for other students to argue or comment if there are less fit their ideas. S1 provides reinforcement after no more students who commented on the presentation of the students' answers. There are things that need to be improved from the practice of teaching knowledge of S1, ie: not using instructional media and learning resources are used only as worksheets and textbooks. The valuation technique used S1 is the observation of student activity and giving a quiz. At the end of S1 lesson invites students to conclude that the material being studied. Of such exposure could be concluded that the practice of knowledge of teaching of S1 is at "level 2".

The practice of knowledge of learners of S1 also looks very good. This is demonstrated by always around to monitor the work of students at the same time provide assistance if there are students who feel confused or have problems as long as the students do chores as Figure 8 below.

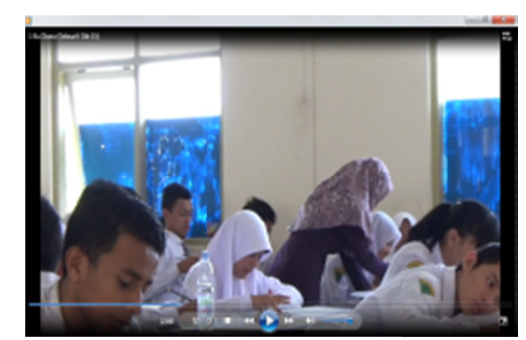

Figure 8. Instructional video screenshot of S1 part 2

Moreover, any opinion was given by S1 students always appreciated though that opinion may be less precise. In communicating with students S1 also looks pretty good, which it is visible at the time of S1 provides an explanation in front of the class as well as provide an explanation at the time of S1 around watching the student's work. S1 ability to engage students in learning process is also very good, as seen during the learning S1 have a reduced role as a demonstrator, but more often to facilitate and assist students in learning. Therefore, the general practice of knowledge of learners of S1 can be categorized into the "level 2".

In identifying the concept LETV and SLETV, S1 has been demonstrated knowledge and ability are quite good, in addition, to clarifying the concept of S1 provides an illustration in the form of examples and not an example. In addition S1 also provides an example that requires students to think at a higher level, for example, students were told to determine whether the equation $x y+y=3$ is LETV or not. But the analogy, $\mathrm{S} 1$ still made some mistakes such as when students write analogy $m=$ mango, and $a=$ apple, S1 merely provides that the correct response is $a$ $=1 \mathrm{~kg}$ of apples, $m=1 \mathrm{~kg}$ of mango. Whereas the correct analogy is $a=$ price of $1 \mathrm{~kg}$ of apples, $m=$ the price of $1 \mathrm{~kg}$ of mango. But in other cases, S1 already specify exact analogy. Besides, S1 also uses charts to clarify the interpretation SLETV solution. So, in general, it can be concluded that the practice of content knowledge of S1 is at "level 2".

Figure 9 below provides an illustration of the change of PCK of S1 and its implementation in teaching practice. And figure 10 whereas the comparison PCK and implementation of the PCK in the teaching practice of S1 on each component. 


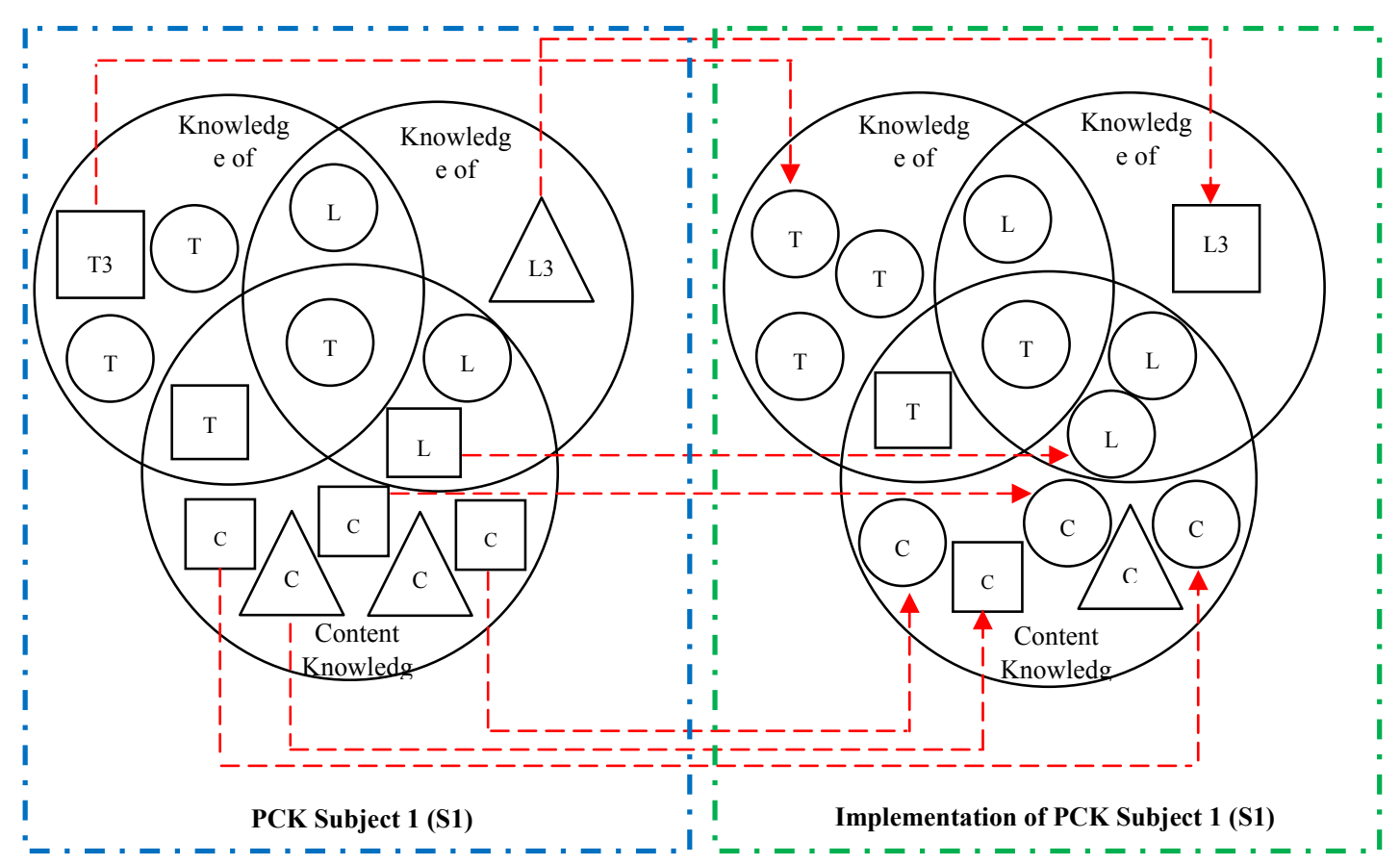

Figure 9. PCK and implementation of PCK Subject 1 (S1)

\section{Information:

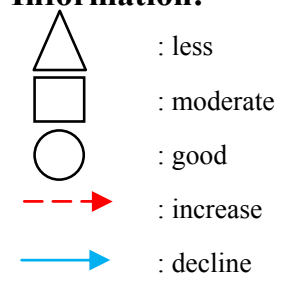

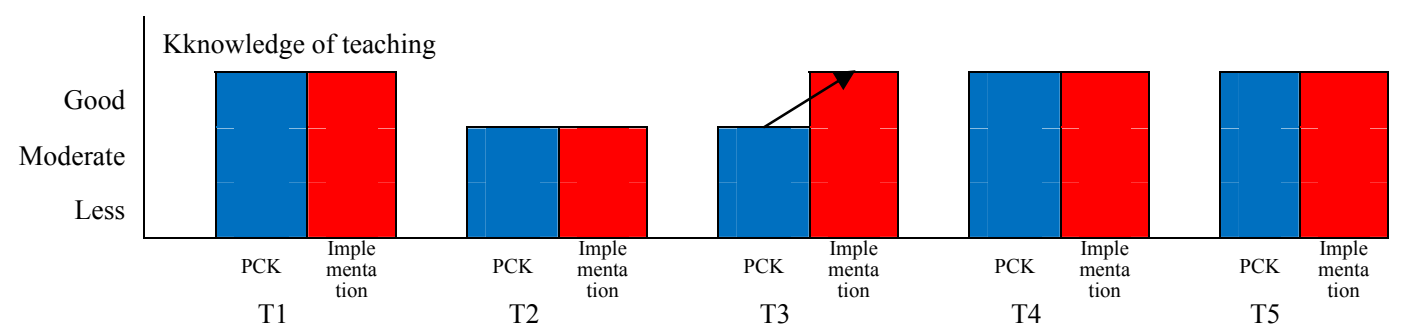
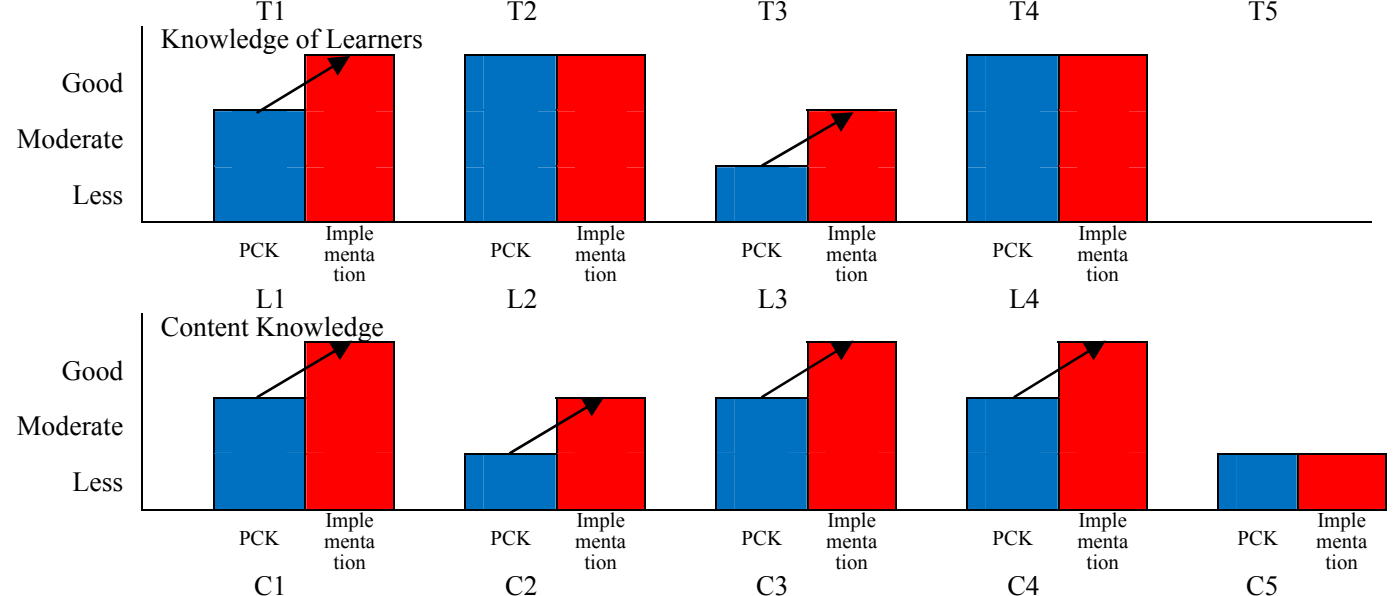

Figure 10. Comparison PCK and implementation of PCK Subject 1 (S1) on each component 
Table 2. Description code from the Figure 9 and Figure 10

\begin{tabular}{|c|c|c|c|}
\hline Code & & PCK of subject 1 (S1) & Implementation of PCK of subject 1 (S1) \\
\hline & & \multicolumn{2}{|c|}{ Knowledge of Teaching } \\
\hline $\mathrm{T} 1$ & : & $\begin{array}{l}\text { Write down the meaning of } 0=0 \text { and } 0=1 \text { to the } \\
\text { possibility of solution of SLETV }\end{array}$ & $\begin{array}{l}\text { Explain the meaning of } 0=0 \text { and } 0=1 \text { to the possibility } \\
\text { of solution of SLETV }\end{array}$ \\
\hline $\mathrm{T} 2$ & : & Write down the apersepsi on material SLETV & Give apersepsi on material SLETV \\
\hline $\mathrm{T} 3$ & : & Write down the assessment of student work & Give the assessment of student work \\
\hline $\mathrm{T} 4$ & : & $\begin{array}{l}\text { Explains the types of evaluation that will be conducted } \\
\text { both test and non test }\end{array}$ & $\begin{array}{l}\text { Evaluate the form of the test (quiz) and non test } \\
\text { (observation of student performance) }\end{array}$ \\
\hline \multirow[t]{2}{*}{$\mathrm{T} 5$} & : & Writing down learning steps in detail & Implementing the learning steps in detail \\
\hline & & \multicolumn{2}{|c|}{ Knowledge of Learners } \\
\hline L1 & : & Explains how diagnose students fault and trouble & Diagnose students fault and trouble \\
\hline $\mathrm{L} 2$ & : & $\begin{array}{l}\text { Explains how to provide assistance to students in solving } \\
\text { problems }\end{array}$ & Provide assistance to students in solving problems \\
\hline L3 & : & Write down the importance of the material to students & Explains the importance of the material to students \\
\hline \multirow[t]{2}{*}{ L4 } & : & Explains how to engage students in learning & Engage students in learning \\
\hline & & \multicolumn{2}{|c|}{ Content Knowledge } \\
\hline $\mathrm{C} 1$ & : & Write down the terms of SLETV & Explain the terms of SLETV \\
\hline $\mathrm{C} 2$ & : & Write down the analogy of word problems into variables & Expalins the analogy of word problems into variables \\
\hline $\mathrm{C} 3$ & . & $\begin{array}{l}\text { Explaining the conceptual and procedural knowledge in } \\
\text { SLETV }\end{array}$ & $\begin{array}{l}\text { Shows the conceptual and procedural knowledge in } \\
\text { SLETV }\end{array}$ \\
\hline $\mathrm{C} 4$ & : & Writing out the graphical representation of SLETV & Use the graphical representation of SLETV \\
\hline $\mathrm{C} 5$ & : & Write down the material prerequisites of SLETV & Explain the material prerequisites of SLETV \\
\hline
\end{tabular}

Based on the above analysis it can be concluded that the overall implementation of PCK S1 during teaching practice has increased from its PCK portrait. Although S1 still has three years of teaching experience, but S1 already has a teaching certificate obtained through the Professional Teacher Education Program. This is likely to affect the increase. It is slightly at odds with the findings of the Black (2008) that the observations of classroom instructional practices of teachers before and after professional development showed little difference in content knowledge and pedagogical content knowledge of them. Besides the improvement that occurred in the implementation of PCK S1 is also influenced by the context (in this case is the environment and students). Classes are taught by $\mathrm{S} 1$ is a class majoring in science in general interest in the learning of mathematics is higher than the other majors. Knowledge of the context mentioned by many researchers as an important component of pedagogical content knowledge (Abd Rahman \& Scaife, 2005; Grossman, 1990; Marks, 1990; Veal \& MaKinster, 1999). Besides According Subanji (2015) PCK be the main thing for the development of teacher competence. By mastering pedagogical content at the same time, teachers will be easy to make students learn optimally. This can happen because the teacher will understand how the process of knowledge construction by students. By understanding the process of "construction by students" will help the teacher to be able to prepare lesson plans, activity sheets, and learning media as well. In addition Improved performance of professional and self-actualization shows their ongoing efforts to improve the professionalism of the teacher himself. This is in accordance with the duties and obligations of teachers in improving the professionalism of self-sustainability (Subanji, 2015).

\subsection{Subject 2 (S2)}

\subsubsection{PCK Subject 2 (S2)}

S2 have shown an ability to construct meaning and understanding to students, for example, to understand the meaning $0=1$, and $0=0$ on the results of elimination or substitution. First, it must be understood that the solution of SLETV using the graph is the intersection of the two lines further students are asked to draw a graph of SLETV. This is as evident in the response S2 in the case 2 of vignette below. 


\begin{tabular}{|c|c|}
\hline 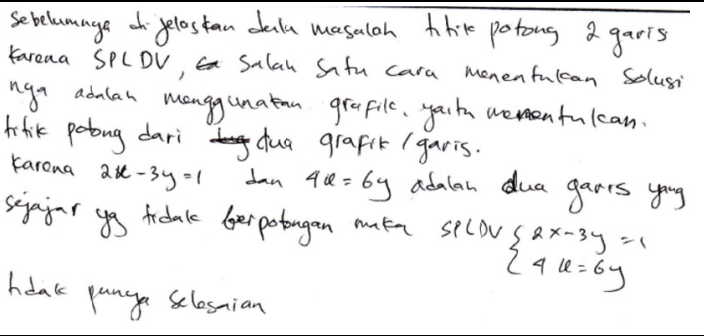 & $\begin{array}{l}\text { Translate in English: } \\
\text { Previously described first problem because the } \\
\text { point of intersection of two lines SLETV, one way } \\
\text { of determining the solution is to use a graph, which } \\
\text { determines the intersection of the two graphs / line. } \\
\text { due to } 2 x-3 y=1 \text { and } 4 x=6 \text { are two parallel lines } \\
\text { that do not intersect the SLETV } 2 x-3 y=1 \text { and } 4 x \\
=6 \text { does not have a solution. }\end{array}$ \\
\hline
\end{tabular}

Figure 11. Response of S2 in vignette case 2

For the case $0=1$ SLETV if drawn the graph in the form of two parallel lines, so it does not have a cut-off point. As for the case $0=0$ SLETV if drawn the graph in the form of two lines coincides, so the point of intersection is infinitely many. Besides S2 also has another alternative is to write the results of the example as $0 y=1$ and $0 y=0$, from the shape of the expected students can find relevant conclusions SLETV solution. This is as shown in the following interview excerpt:

\begin{tabular}{|c|c|c|}
\hline$P$ & $\therefore$ & $\begin{array}{l}\text { Well, now we get into the case 2. In this second case your answer using annotations to the graphical method. Well if } \\
\text { you must know that if a settlement SLETV represented in graph form of what? }\end{array}$ \\
\hline$S 2$ & $\therefore$ & ( \\
\hline$P$ & $\therefore$ & ther explanations be \\
\hline$I M$ & & $\begin{array}{l}\text { Well Sir, the equation } 0=1 \text { that we write in the form of } 0 x=1 \text {, or } 0 Y=1 \text {, so that here there is no value of } x \text { and } y \\
\text { that satisfy the equation. Thus concluded does not have a solution. }\end{array}$ \\
\hline
\end{tabular}

On the other side, S2 is still lacking in mentioning the prerequisite knowledge are needed in studying this material. As related to his role as assessor and reminders, S2 has been able to assess the results of the students' work very well, but it also uses the assessment process (group work), assignments and formative tests. The steps have not prepared a detailed study and sequence and did not reflect the learning activities that enable the students. Likewise in formulating learning goals, S2 only able to formulate objectives SLETV with enough category. Based on the description then generally it can be said that the knowledge of teaching of S2 is at "level 1".

Additionally, S2 has been able to make a diagnosis of students' mistakes, and be able to explain the solution. For example, S2 can determine the position of the mistakes made by students during the linear equation multiply by 3 , and can explain how the answer should have been, as a response to the case 5 of vignette as follows.

\begin{tabular}{|c|c|}
\hline Bagaimana Bapak/lbu memperbaikikesalahan yang dil & Translate in English: \\
\hline 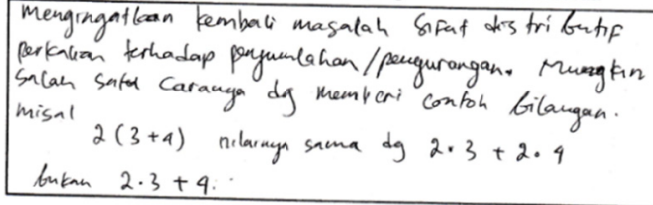 & $\begin{array}{l}\text { How do you fix the mistakes made by the student? } \\
\text { Recalls the distributive property of multiplication } \\
\text { to the addition/subtraction. May be one way to } \\
\text { provide an example using numbers. Example } \\
2(3+4) \text { is equal to } 2.4 \text { instead of } 2.3+2.3+4\end{array}$ \\
\hline
\end{tabular}

Figure 12. Response of S2 in vignette case 5

Likewise, based on teaching experience S2 is able to mention the difficulties normally experienced by students in these materials, namely: the difficulty drawing graphs and difficulty letting variables in terms of the story. As in facilitating students to solve problems, S2 demonstrated well. For example, to guide students in solving SLETV, if it produces $0=1$ or $0=0$ at the time eliminated or substituted, the students are asked to write down the results of the example as $0 y=1$ and $0 y=0 . \mathrm{S} 2$ capabilities in explaining the importance of the materials delivered still needs to be developed. Further associated with learning resources S2 only mention learning resources ie books and worksheets, not to mention other sources like the internet and the classroom environment. Based on the description, in general, it can be concluded that the knowledge of learners S2 is at "level 2".

S2 is able to mention a sufficient condition SLETV and able to state the relationship between solution of SLETV and the graph representation. S2 has also been very good in addressing the analogy $x=$ notebooks and $y=$ pencils, and could indicate a more appropriate analogy, namely $x=$ price of 1 notebooks and $y=$ price of 1 pencils. It's as seen from the response S2 to case 1 of vignette as follows. 


\begin{tabular}{|c|c|}
\hline $\begin{array}{l}\text { Memisal kannya masih kurang tepat, seharusnge } \\
\text { ke adalah harya } 1 \text { bukn tules } \\
\text { y -... harga } 1 \text { pensil. } \\
\text { untuk proses mengerjaken sudan berar. }\end{array}$ & $\begin{array}{l}\text { Translate in English: } \\
\text { In inserting still not quite right, it should } \\
x \text { is the price of } 1 \text { notebook } \\
y \text { is the price of one pencil } \\
\text { for the process is correct }\end{array}$ \\
\hline
\end{tabular}

Figure 13. Response of S2 in vignette case 1

Likewise in the principles of solution methods and principles SLETV multiplying the equation by a constant, S2 already understand well. Additionally, S2 has been able to mention the material prerequisites for the material SLETV although it is limited as a response S2 to the CoRe 4 below.

\begin{tabular}{|c|c|c|c|c|c|}
\hline 4. & \begin{tabular}{|l|} 
Materi dan \\
keterampilan pra- \\
syarat apa saja \\
yang harus dimiliki \\
siswa supaya bisa \\
memahami konsep \\
ini dengan baik?
\end{tabular} & operasi Alg & $\begin{array}{l}\text { Opera } \\
\text { gare }\end{array}$ & Aljubar, mangganlar & $\begin{array}{l}\text { operasi Algabar. monggambur } \\
\text { garrs }\end{array}$ \\
\hline \multicolumn{6}{|c|}{ Translate in English: } \\
\hline 44. & \multicolumn{2}{|c|}{$\begin{array}{l}\text { a. What is the Material and } \\
\text { any prerequisite skills } \\
\text { students need to have in } \\
\text { order to understand this } \\
\text { concept well? }\end{array}$} & algebra operations & $\begin{array}{l}\text { algebra operations, } \\
\text { drawing a line }\end{array}$ & $\begin{array}{l}\text { algebra operations, } \\
\text { drawing a line }\end{array}$ \\
\hline
\end{tabular}

Figure 14. Response of S2 in CoRe 4

On the other side S2 less able to mention the conceptual and procedural knowledge required in SLETV material. So in general, content knowledge of S2 is at "level 2".

\subsubsection{Implementation of PCK of Subject 2}

In lessons, S2 is not optimal in creating a coherent teaching. For example in initiating SLETV material, S2 has not submitted the learning objectives be achieved and also not put the points of the material that the students will learn sequentially. In addition, S2 is enough to use questioning and discussion. This was seen during the study, at the first meeting S2 dominating role as demonstrator (Figure 15) but in the second meeting S2 is a lot of discussion and question and answer session with the students rather than explaining the lecture method.

S2 use the assessment process, namely through the observation of performance (activity) students in the group and at the time of presentation. However, at the end of the lesson S2 has not a reflection by getting students to conclude that the material being studied. So generally can be inferred from the practice of knowledge of teaching $\mathrm{S} 2$ is at "level 0".

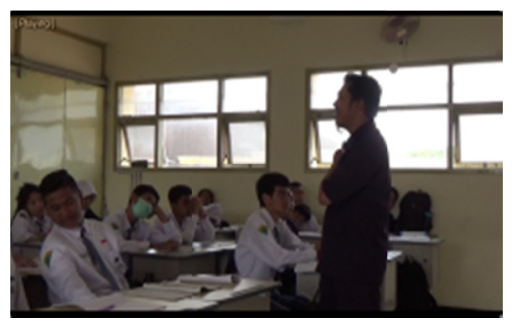

Figure 15. Instructional video screenshot of S2 part 1

During learning, especially in the second meeting, S2 is often seen helping students to understand and solve problems SLETV. S2 uses easy explanation accepted students, for example when students are confused by analogy $x=$ mango, $y=$ apple, $\mathrm{S} 2$ provide awareness to students by restoring the sentences of mathematics derived to sentences about the story, so that students can know, where errors in analogy made (Figure 16). But S2 still occasionally seen engaging students in learning. In addition, because of poor time management, S2 often 
dominate certain material explanation. It is an evident lack of giving students the chance to argue after the presentation of the group is completed. It can therefore be concluded that the practice of knowledge of learners of S2 is at "level 1".

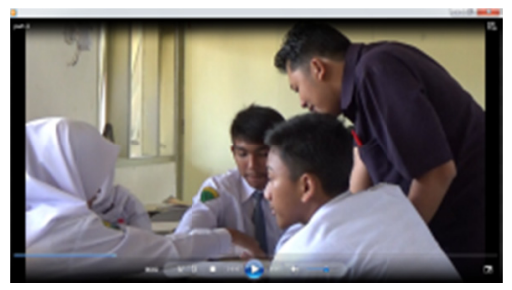

Figure 16. Instructional video screenshot of S2 part 2

S2 has shown good content knowledge in teaching practice. For example in letting variable from about the story and explain the procedure in SLETV solution method. Similarly, when explaining the meaning $0=0$ from the elimination. Therefore, the practice of the content knowledge of S2 is at "level 2".

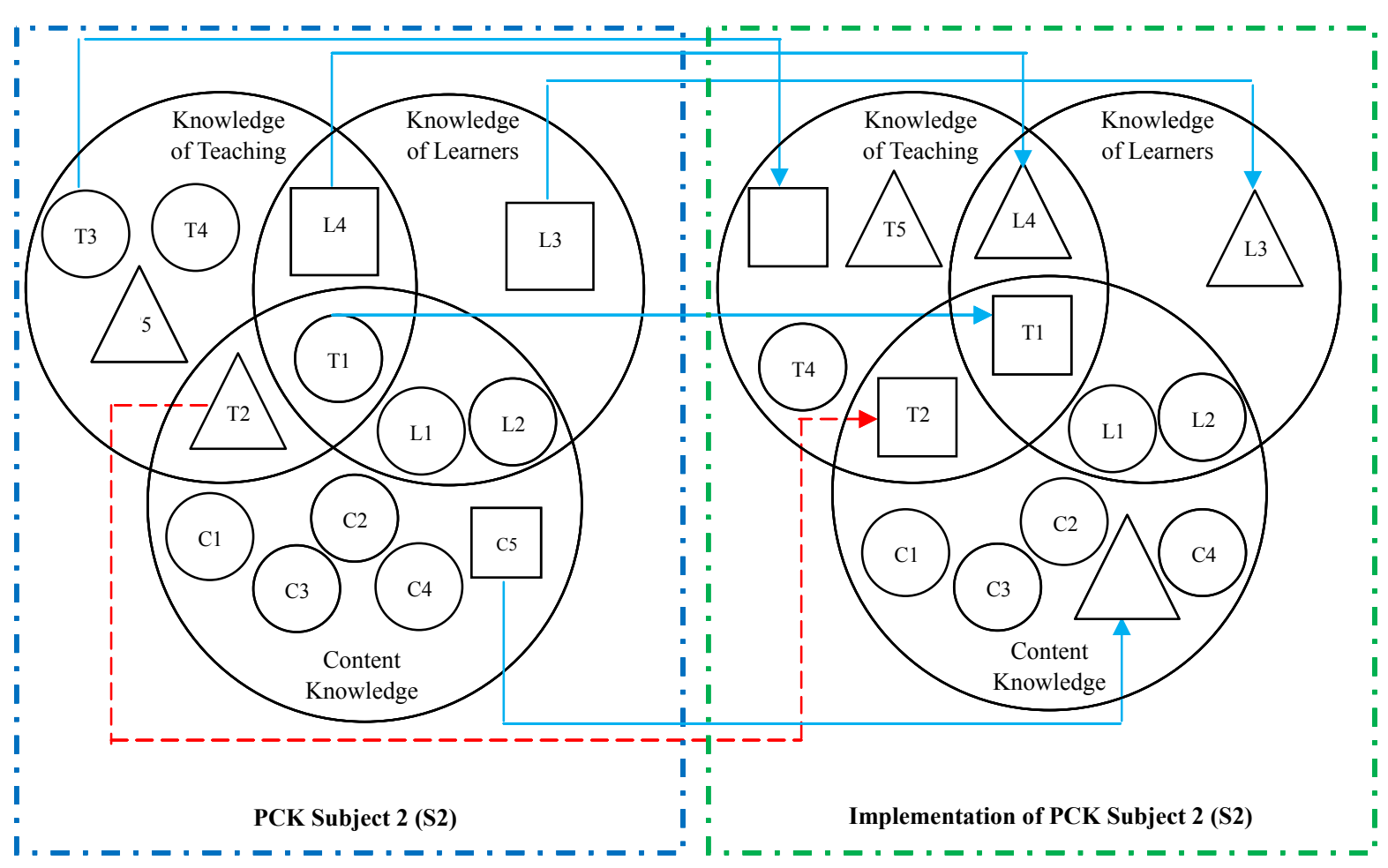

Figure 17. PCK and implementation of PCK Subject 2 (S2) 


\section{Information:

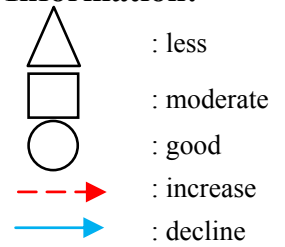

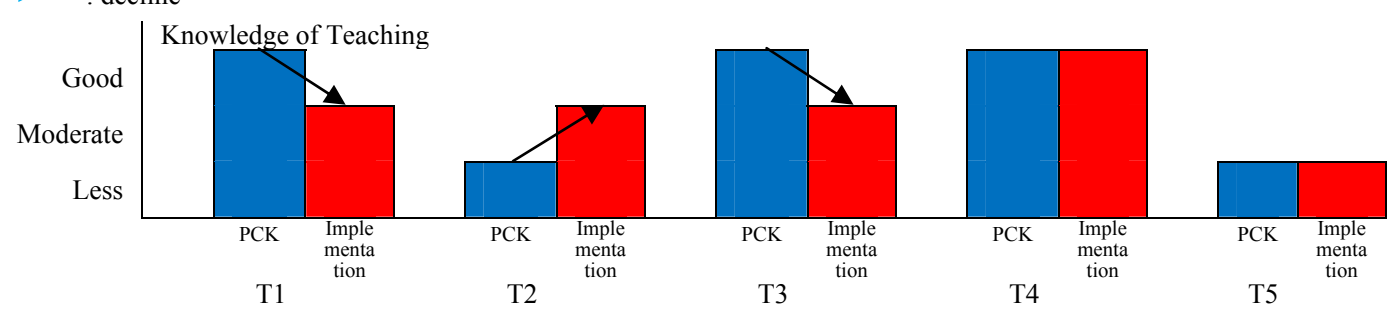
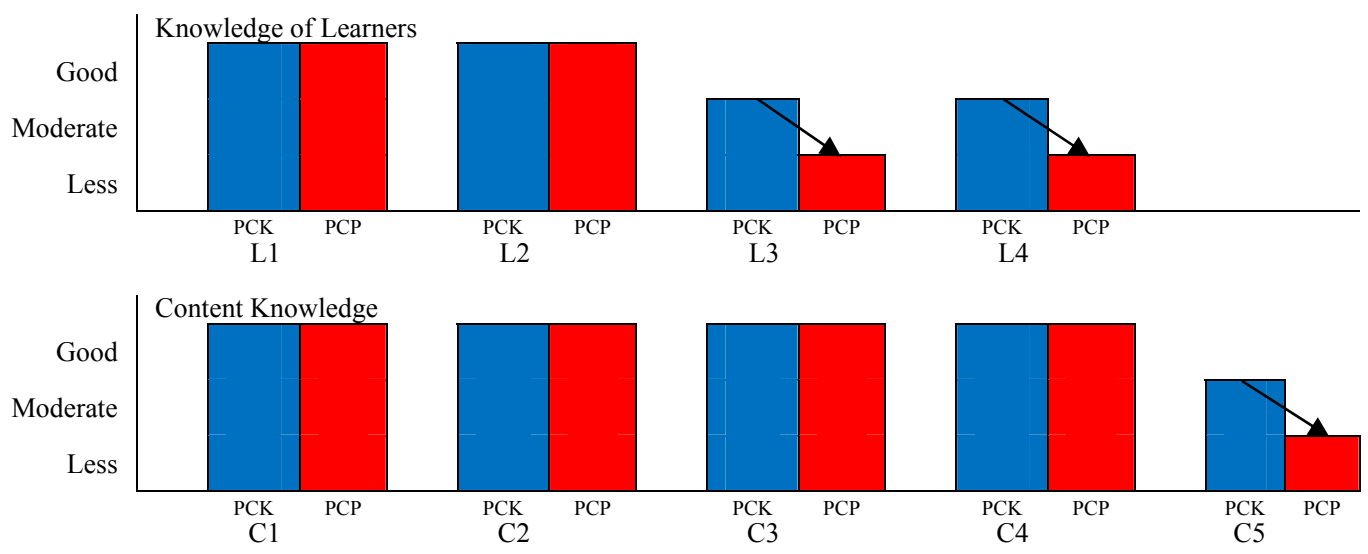

Figure 18. Comparison PCK and implementation of PCK Subject 2 (S2) on each component

Table 3. Description code from the Figure 17 and Figure 18

\begin{tabular}{|c|c|c|c|}
\hline Code & & PCK of subject 2 (S2) & Implementation of PCK of subject 2 (S2) \\
\hline & & \multicolumn{2}{|c|}{ Knowledge of Teaching } \\
\hline $\mathrm{T} 1$ & $:$ & $\begin{array}{l}\text { Write down the meaning of } 0=0 \text { and } 0=1 \text { to the } \\
\text { possibility of solution of SLETV }\end{array}$ & $\begin{array}{l}\text { Explain the meaning of } 0=0 \text { and } 0=1 \text { to the possibility } \\
\text { of solution of SLETV }\end{array}$ \\
\hline $\mathrm{T} 2$ & $:$ & Write down the apersepsi on material SLETV & Give apersepsi on material SLETV \\
\hline $\mathrm{T} 3$ & $:$ & Write down the assessment of student work & Give the assessment of student work \\
\hline $\mathrm{T} 4$ & : & $\begin{array}{l}\text { Explains the types of evaluation that will be conducted } \\
\text { both test and non test }\end{array}$ & $\begin{array}{l}\text { Evaluate the form of the test (quiz) and non test } \\
\text { (observation of student performance) }\end{array}$ \\
\hline \multirow[t]{2}{*}{ T5 } & $:$ & Writing down learning steps in detail & Implementing the learning steps in detail \\
\hline & & \multicolumn{2}{|c|}{ Knowledge of Learners } \\
\hline L1 & $:$ & Explains how diagnose students fault and trouble & Diagnose students fault and trouble \\
\hline L2 & $:$ & $\begin{array}{l}\text { Explains how to provide assistance to students in solving } \\
\text { problems }\end{array}$ & Provide assistance to students in solving problems \\
\hline L3 & $:$ & Write down the importance of the material to students & Explains the importance of the material to students \\
\hline \multirow[t]{2}{*}{ L4 } & $:$ & Explains how to engage students in learning & Engage students in learning \\
\hline & & \multicolumn{2}{|c|}{ Content Knowledge } \\
\hline $\mathrm{C} 1$ & $:$ & Write down the terms of SLETV & Explain the terms of SLETV \\
\hline $\mathrm{C} 2$ & $:$ & Write down the analogy of word problems into variables & Expalins the analogy of word problems into variables \\
\hline $\mathrm{C} 3$ & $:$ & $\begin{array}{l}\text { Explaining the conceptual and procedural knowledge in } \\
\text { SLETV }\end{array}$ & $\begin{array}{l}\text { Shows the conceptual and procedural knowledge in } \\
\text { SLETV }\end{array}$ \\
\hline $\mathrm{C} 4$ & $:$ & Writing out the graphical representation of SLETV & Use the graphical representation of SLETV \\
\hline $\mathrm{C} 5$ & $:$ & Write down the material prerequisites of SLETV & Explain the material prerequisites of SLETV \\
\hline
\end{tabular}

Figure 17 and Figure 18 above provides an illustration of the change PCK of S2 and its implementation in 
teaching practice.

In the component of knowledge and teaching practices, portrait PCK and implemntation of PCK of S2 are shifting down. Yet judging from the work experience, S2 have the life of over 5 years. It is slightly at odds with the opinion Gatbonton (2008) that a group of experienced teachers has the pedagogical knowledge that is more detailed, particularly in regards students' attitudes and behavior. In lessons, S2 use the lecture method. According to Anthony and Walshaw (2009), when a teacher uses lectures, he dominated the information while students passively listening. Anthony and Walshaw shows that effective teachers encourage class activity in question is planned with care that encourages students to speak their mathematical ideas about mathematical concepts. As for the components of the knowledge of the students and their teaching practices, S2 has a shift from the PCK to implentation PCK in teaching practice by category down. Even and Tirosh (1995) investigated the teacher's knowledge of the students and found that teachers are reluctant to try to understand the source of the students' responses although they need this information to make appropriate instructional decisions to help students learn. When students give a wrong answer they tend to explain the correct answers rather than asking students how they find the answer. Thus, they miss the opportunity to detect gaps in students' understanding of mathematics and helping them to construct their mathematical knowledge.

Li (2009) in his research concluded that PCK mathematics teachers have an impact on the teaching they do is apparent not only from the object of teaching, structure of teaching, and the idea of explaining, but also from the view of education, emotional teaching, teaching design, teaching language, mathematical thinking students, student learning attitude and so on. This decrease is also due to the lack of precise time and context management (environment and students) as Abd Rahman \& Scaife (2005) opinions.

\section{Conclusion}

S1 PCK shift in the practice of teaching to the category of "shifting it up" particularly on the component of the knowledge of learners and content knowledge, while the S2 PCK shift in the practice of teaching to the category of "shift down" particularly on the component knowledge of teaching and knowledge of learners. Things that affect the increase or decrease in the implementation of the PCK are professional training for teachers who have been followed, the context (the classroom environment and the students taught), time management learning and teaching experience.

\section{References}

Abd Rahman, F., \& Scaife, J. A. (2005). Assessing pre service teachers pedagogical content knowledge using a bricolage approach. The Twelfth Learning Conference on Learning-in the Faculty of Education at the University of Granada.

Anthony, G., \& Walshaw, M. (2009). Characteristics of Effective Teaching of Mathematics: A View from the West. Journal of Mathematics Education, 2(2), 147-164.

Black, J. W. (2008). Content Knowledge and Pedagogical Content Knowledge of Algebra Teachers and Changes in Both Types of Knowledge as a Result of Professional Development. Proceedings of the 5th Annual TEAM-Math Partnership Conference Pre-Session (pp. 30-40).

Bloomberg, L. D., \& Volpe, M. (2008). Completing Your Qualitative Dissertation. Singapore: Sage Publication.

Boaler, J. (2003). Studying and capturing the complexity of practice: The case of the dance of agency. In N. Pateman, B. J. Dougherty, \& J. T. Zilliox (Eds.), Proceedings of the 27th PME International Conference, 1, 3-16.

Ebert, C. L. (1993). An assessment of prospective secondary teachers pedagogical content knowledge about functions and graphs. Paper presented at the annual meeting of the American Educational Research Association, Atlanta.

Eggen, P., \& Kauchak, D. (2007). Educational Psychology Windows on Classroom (7th ed.). New Jersey: Pearson Education, Inc.

Even, R., \& Schwarz, B. B. (2002). Implications of competing interpretations of practice to research and theory in mathematics education. In A. D. Cokburn, \& E. Nardi (Eds.), Proceedings of the 26th PME International Conference, 2, 337-344.

Even, R., \& Tirosh, D. (1995). Subject-matter knowledge and knowledge about students as sources of teacher presentations of the subject-matter. Educational Studies in Mathematics, 29, 1-20. https://doi.org/10.1007/BF01273897 
Gatbonton, E. (2008). Looking beyond teachers' classroom behaviour: Novice and experience ESL teachers' pedagogical knowledge. Language Teaching Research, 12(2), 161-182. https://doi.org/10.1177/1362168807086286

Grossman, P. L. (1990). The making of a teacher: Teacher knowledge and teacher education. New York: Teachers College Press.

Karahasan, B. (2010). Preservice Secondary Mathematics Teachers Pedagogical Content Knowledge of Composite and Inverse Functions (Unpublished doctoral dissertation). Secondary Science and Mathematics Education Department, Middle East Technical University, Turki.

Li, M. (2009). Study on Effect of Mathematics Teachers' Pedagogical Content Knowledge on Mathematics Teaching. Journal of Mathematics Education, 2(1), 55-68.

Marks, R. (1990). Pedagogical content knowledge: From a mathematical case to a modified conception. Journal of Teacher Education, 4l(3), 3-11. https://doi.org/10.1177/002248719004100302

Rollnick, M., Bennett, J., Rhemtula, N. D., \& Ndlovu, T. (2008). The place of subject matter knowledge in pedagogical content knowledge: Acase study of South African teachers teaching the amount of substance and chemical equilibrium. International Journal of Science Education, 30(10), 1365-1387. https://doi.org/10.1080/09500690802187025

Saxe, G. B. (1999). Professional development, classroom practices, and students' mathematics learning: A cultural perspective. In O. Zaslavsky (Ed.), Proceedings of the 23rd PME International Conference, 1, 25-39.

Shulman, L. S. (1986). Those who understand: Knowledge growth in teaching. Educational Researcher, 15(2), 4-14. https://doi.org/10.2307/1175860

Simon, M., \& Tzur, R. (1997). Generalizing theoretical accounts of mathematics teachers' practices. In H. Pekhonen (Ed.), Proceedings of the 21st PME Conference, 4, 160-167.

Skott, J. (1999). The multiple motives of teacher activity and the roles of the teachers school mathematical images. In O. Zaslavsky (Ed.), Proceedings of the 23rd PME International Conference, 4, 209-216.

Subanji. (2015). Peningkatan Kinerja Guru Indonesia: Sebuah Refleksi 5 Tahun Perjalanan TEQIP. Jurnal TEQIP Tahun VI, Nomor 2, November 2015.

Thompson, A. G. (1991). The development of teachers conceptions of mathematics teaching. Proceedings of the Thirteenth Annual Meeting of the North American Chapter of the International Group for the Psychology of Mathematics Education, 2, 8-14.

Veal, W., \& MaKinster, J. (1999). Pedagogical content knowledge taxonomies. Electronic Journal of Science Education, 3(4), 47-56.

\section{Copyrights}

Copyright for this article is retained by the author(s), with first publication rights granted to the journal.

This is an open-access article distributed under the terms and conditions of the Creative Commons Attribution license (http://creativecommons.org/licenses/by/4.0/). 